\title{
Sanal ve Nesnel Teknolojik Öğretim Araçlarını Kullanarak Fen Bilimleri Ders Materyali Geliştirmesine Yönelik Örnek Çalışmalar*
}

\section{Mahmut AYAZ** , Nasip DEMIRKUŞ***}

Öz: Çalışmanın amacı, eğitim öğretim sürecinde kavram öğretimi kalitesini artırmak için kullanabilecek sanal ve nesnel materyallerin nasıl geliştirilebileceğine yönelik örnek uygulamalar ortaya koymaya çalışmaktır. Bu çalışmada etkin ve verimli ders anlatımını kolaylaştırmak için sanal ders materyalleri hazırlanmıştır. Çalışmada karma yöntem kullanılmıştır. Çalışmanın nicel boyutunda yarı deneysel desen, nitel boyutunda ise doküman incelemesi ve analizi kullanılmıştır. Bu amaç doğrultusunda ilk, orta, lise ve yükseköğretim düzeyinde kullanılabilecek toplam 23 adet görsel, işitsel, görsel + işitsel, yazımsal ve internet bağlantılı orijinal uygulama ve etkinlik sunusu hazırlanmıştır. Hazırlanan sanal ve nesnel ders materyallerinin tümü 25 farklı başlık altında toplanarak, internet entegreli olarak DVD'de sunum haline getirilmiştir. Biyoloji eğitimi web sayfasında, çalışma ile ilgili tüm envanterler http://www.biyolojiegitim.yyu.edu.tr/ozgecmis/matez.pdf internet sayfası üzerinde herkesin hizmetine sunulmuştur. Ayrıca bu materyallerin eğitim-öğretim ortamında örnek kullanımı sağlanmış ve olumlu sonuçlar alınmıştır.

Anahtar Kelimeler: Kavram Araçları, Sanal ve Nesnel Araçlar, Fen Kavramları

\footnotetext{
*Bu çalışma Kavramsal Araçlara ve Kavramsal İlişkilere Dayalı Fen Bilgisinde Ders Materyali Geliştirmek adlı yüksek lisans tezinin bir bölümüdür.

** Milli Eğitim Bakanlığı, Tuşba/Van. mahmutzaya@hotmail.com

***Prof. Dr. Yüzüncü Y1l Üniversitesi, Eğitim Fakültesi, Biyoloji Eğitim Bölümü. nasip@ hotmail.com, http://orcid.org/0000-0003-4195-070X
} 


\section{Example Works in the Development of Course Materials in Science Course Using Virtual and Objective Technological Teaching Tools}

Abstract: In this study, developed virtual course materials were prepared to facilitate effective and efficient lectures. The purpose of the study is to improve virtual materials that can be used to increase the quality of concept education through putting forward sample applications during the education process. A mixed method was used in the study. Semiexperimental design was used in the quantitative dimension of the study, and document research and analysis was used in the qualitative dimension .For this purpose a totally, 23 pieces of visual, auditory, visual + auditory, written and internet based original applications and activity of presentations, which can be used at primary, secondary and collage levels, were prepared. The entire thesis and course material prepared under 25 different titles were collected and were integrated with the Internet as a presentation then was made into a DVD. All inventory about thesis is available for everyone on biology education web page: http://www.biyolojiegitim.yyu.edu.tr/ozgecmis/matez.pdf. In addition, these materials were used in the educational environment and positive results were obtained.

Keywords: Concept Tools, Virtual and Objective Tools, Science Concepts 


\section{Giriş}

Dünya'nın tüm kültür dillerindeki pek çok kural, kavram, isim ve semboller; ilişkisel, anlamsal, şekilsel olarak düşünüldüğünde hepsinin doğal kökenli olduğu anlaşılır (Demirkuş, 2017a). Sonradan bu dillerin doğal oluşum kurallarına insani mantıksal bazı katkılar ilave edilmiştir. Bu katkılardan ve dil kurallarının kökeninden dolayı kavramlarda kullanımda ya da uygulamalarda düşünce ve algıda yanılgıya neden olmaktadır. Bunun doğal sonucu olarak kavram öğretiminde ve iletişimdeki kavramsal seviyelerde algıda değişkenliklere ve yanılgılara neden olmaktadır (Taş, Gülen, Öner ve Özyürek, 2015). Bu konuda kısa vadede başarıya ve çözüme ulaşmanın bir yolu da; kavram ve isim kümelerini kavram iletişim araçlarıyla düzenlemektir (Gülen ve Demirkuş, 2014a; 2014b). Belki de uzun vadede insanlığın iletişimde algıda değişmezliğe yaklaşması için; tüm kültür dilleriyle etkili bir şekilde uyumlu kullanılabilen; matematik iletişim diline ve mantı̆̆ına benzer yapay mantıksal bir alfabe, dil ve lisanı yaratması gerekir (Demirkuş, 2017a).

Kavramlar, bazı sembollerin beyinsel ve zihinsel havuzumuzda yer alan bilgi birimlerini, gerek eğitim-öğretim gerekse toplumsal ve kültürel iletişimin yapı taşlarını oluşturur (Ayaz, 2010; Demirkuş, 2017b; Gülen, 2010).

Beyinsel ve zihinsel olarak dağarcığımıza giren bilgileri temsil eden kavramların özellikleri, özgünlükleri, birbirleriyle ilişkisel örüntüleri ve dağarcığımıza kodlanış biçimlerinin mekanizmaları eğitim-öğretimde etkili bir şekilde kullanılmalıdır (Ayaz, 2010; Demirkuş, 2017a). Bu amaçla; kavram, isim ve bilgileri temsil eden sembollerin yapılagelen en son kapsamlı ve anlaşılabilir orijinal tanımları ve ilişkileri örnekler ve uygulamalarla ortaya konulmalıdır.

Kavram öğretimi en önemli noktalardan biri kavramın öğretiminde kullanılan materyallerdir (Taş, 2011). Öğretim materyalleri, öğrenme sürecinde öğrenciye sunulan 
araçlardır. Basılı materyaller, fotoğraflar, maketler, ses kasetleri, videolar, CD’ler, internet sayfaları, çeşitli yazılımlar birer öğretim materyalidir (Kaya, 2006; Yelken, 2009). Bu materyallerin hazırlanmasında dersin içeriği, öğrenme yaklaşımı ve hedef kitle belirleyici unsurlardır (Bayram, 2006; Dalmış11, 2013; Seferoğlu, 2006). Materyalin hazırlanmasında söz konusu unsurlar ışı̆̆ında gerekli ön inceleme yapılıp tasarıma geçildiğinde olanaklar göz önüne alınır. Bireyler zaman içerisinde imkânları ölçüsünde materyal geliştirebilmişlerdir (Akalan, 2012; Alev, 2004). Nitekim 21. yüzy1l içerisinde teknolojinin bu kadar gelişmiş olması ve Milli Eğitim Bakanlığı'nın (MEB) Fırsatları Artırma ve Teknolojinin İyileştirmesi (FATİH)'ne yönelik devasa projeleri de göz önüne alındığında öğretim materyallerinin hazırlanmasında kullanılabilecek imkânların teknolojik olduğu anlaşılmaktadır (Gülen, 2016a; Şahin, 2016).

Günümüzde televizyon, tablet ve en önemlisi cep telefonlarının hızlı bir şekilde yaygınlaşması ve buna paralel olarak sosyal paylaşım hesaplarının çığ gibi büyümesi eğitimdeki bir diğer imkânı göstermektedir (Aydemir Özyurt, 2016; Çakır, 2014; Halls, 2012). Araştırmacılar, öğrenciler üzerindeki çalışmalarında, cep telefonu kullanımı, sosyal paylaşım hesaplarının kullanımı, haberleşme-paylaşma ve sunum yapma gibi aktivitelerin en çok oranda tercih edildiğini keşfetmişlerdir (Ata ve Atik, 2016; Blanton, 2005; Bonostre ve Pina, 2006). Burada fark edilmektedir ki eğitim ortamında istenilen hedeflerin elde edilmesi için çağın imkanları ile öğrencilerin ilgi alanlarının entegre edilmesi gerekmektedir (Arıkan, 2006; Gülen, 2016a; Gürbüz, 2006). Özellikle fen bilimleri dersinde kavram eğitiminin üzerinde çalışmalar yapıldığında bu unsurların irdelenmesi ve kullanılması amaca ulaşmada fayda sağlayacaktır (Demirkuş, 2017a).

Çağın teknolojik gelişmeleri ve kullanımları ile kavramların eğitim sürecinde yanılgısız ve etkin öğreniminde yapılacak olan entegrasyon, bilgisayar ortamında bulunan sanal programların kullanımı ile olur (Chen, 2008; Demirkuş, 2017b). Burada karşımıza 
çıkan kavram ilişkilendirme araçları; kavram çarkları, kavram kümesi, kavram ilişkilendirme tablosu, kavram ağı, kavram haritası gibi araçlardır (Akmaca Özyılmaz, 2009; Gülen, 2016b). $\mathrm{Bu}$ araçların yöntem bölümünde ayrıntılı açıklanan sanal bilgisayar programlarının kullanılması ve nesnel araçlar yardımıyla fen bilimleri ders konuları ile entegrasyonu sonucu elde edilen ders materyallerinin eğitim hedeflerinin gerçekleştirilmesinde faydalı olacağı düşünülmektedir.

Araştırmanın Önemi: Kavram öğretiminde materyal kullanımının etkisi, şüphesiz tartışılamaz. Kalıcı ve etkili öğrenmede materyalin kullanılması gerekmektedir (Gülen ve Demirkuş, 2014b). Gelişen ve ilerleyen teknolojik çalışmalar ile eğitim sistemimizin yenilik yaparak FATİH projesi ile atağa geçtiği günümüzde sanal ders materyalleri kuşkusuz önemli bir yer tutacaktır (Gülen, 2016a).

Fen bilimleri dersinde kavram ilişkilendirme araçları ve sanal bilgisayar programları kullanılabilen yardımcı ders araçları olarak ele alınabilir. Bu araçların birbiriyle entegrasyonu sonucu öğrencinin fen bilimleri konularına yönelik merak duyduğu veya ulaşamadığı hatta soyut olan kavramları öğrenebildiği tespit edilmiştir (Gülen ve Demirkuş, 2014a; 2014b). Bu çalışmada kavram ilişkilendirme araçları kullanarak sanal ders materyalleri hazırlanmıştır (All, Huycke \& Fisher, 2003). Bu materyaller sanal bilgisayar programlarının kullanımıyla internet ortamına entegre edilmiştir. Çalışmanın bu yönü, kavram öğretimine özgün ve yeni bir perspektif kattığı düşünülmektedir.

Fen bilimleri dersinde bireyin nesnel, sanal ve düşünsel çevrelerini etkili bir şekilde kullanarak ders materyali geliştirmesi için; eğitim alanında hangi yöntemleri, hangi kuralları, hangi sanal araçları, hangi nesnel araçları, hangi argüman gruplarını, hangi ortamlarda nasıl kullanılması gerektiğini özetleyen bilgilerin yer aldığı örnek bir çalışma hazırlanması önem taşımaktadır. 
Araştırmanın Amacı: Eğitim öğretim sürecinde kavram öğretimi kalitesini artırmak için kullanabilecek sanal ve nesnel materyallerin nasıl geliştirilebileceğine yönelik örnek uygulamalar ortaya koymaya çalışmaktır. Fen bilimleri dersleriyle ilişkisel, özgün ve önemli dokümanların sanal bilgisayar programlarının ve kavram ilişkilendirme araçlarının kullanımı ile sınıf ortamında kullanılabilecek sanal ders materyali ve internet erişimi olmayan okullar için DVD hazırlamaktır. Bu materyalin öğrencilerin akademik başarısı üzerindeki etkisini incelemektir.

\section{Yöntem}

Araştırmada karma yöntem kullanılmıştır. Araştırmanın nicel boyutunda yarı deneysel desen, nitel boyutunda ise doküman incelemesi ve analizi kullanılmıştır. Yarı deneysel desen uygulama sınıfinda araştırma sonrası deney ve kontrol gruplarına uygulanan başarı testinin analizi ile sonuçlandırılmıştır. Ayrıca araştırmada materyal geliştirme ilkeleri göz önünde bulundurularak doküman incelemesi yapılmıştır. Doküman incelemesi, verilerin olduğu gibi ele alınıp belli kriterler ışı̆̆ında objektif bir şekilde incelenmesi ve analiz edilmesi olarak bilinir (Çokluk, Yılmaz ve Oğuz, 2011).

Öğretim materyalinin hazırlanmasında dikkat edilecek hususlar kısaca aşağıda verilmiştir. $\mathrm{Bu}$ ilkeler 1şığında hazırlanan materyal alanında uzman iki öğretim üyesi eşliğinde şekillendirilmiştir. Söz konusu ilkeler Demirkuş (2017) ile Gülen ve Demirkuş (2016) çalışmalarından yararlanılarak hazırlanmıştır.

1. Anlamlılık ilkesi: Bir malzeme ne kadar anlamlı ise öğrenilmesi de o kadar kolaydır. Araştırmada kullanılan kavram tanımları düzgün ve kurallı cümleler seçilerek belirtilmiştir. Öğrenciler tarafından anlaşılabilmesi için gezi yerlerinin resimleri üzerine kavramların isimleri yazılmıştır. Ayrıca araştırmacının parça parça çektiği videoların (filmlerin) video editörü (Demo) programıla uygun olmayan bölümleri kesilerek birleştirilmiştir. 
2. Bilinenden başlama ilkesi: Öğretim somuttan soyuta, basitten karmaşığa ve bilinenden bilinmeyene doğru daha kolay ilerlemektedir.

3. Çok örnek ilkesi: Bir kavramın genişliğini göstermek için çok sayıda örnekler sunmak gerekmektedir. Bu amaca bağlı kalarak bir yerin birden fazla resmi çekilmiş ya da aynı yerin farklı açılardan resimleri kullanılmıştır.

4. Görelik ilkesi: Özellikler birbirine göre algılanır. Resim ve şekilleri herkes başka şekilde algılamamalı, birbirinden ayırt edebilmelidir. Bu ilkeye bağlı kalarak hazırladığımız materyalin kullanılan resimlerin net olmasına dikkat edilmiş ve resimler uygun açılardan çekilmiştir. Ayrıca bazı resimlerde isimleri veya tanımları yazılmıştır.

5. Seçicilik ilkesi: Öğretim materyalindeki önemli unsurları dikkati en çok çekecek şekilde yerleştirmek gerekmektedir. Hazırlanan materyalde özellikle verilmek istenen amaca uygun olarak bazı resim ve videolar ön planda tutulmuştur. Ayrıca kavramların tanımları, yazı rengi ve puntolarına dikkat edilmiştir.

6. Tamamlama ilkesi: Bir olayın ya da eşyanın tümüne ilişkin çizgileri vermek yerine bir kısmını vermek yeterli olabilir. Bu amaca bağlı kalarak hazırlanan materyalde ana unsuru belirtebilmek için videodan önce resimler verilmiştir. Örneğin; Muradiye şelalesinde, Şelalenin tümünü anlatan video verilmeden önce şelale ile ilgili resimler verilerek öğrencinin izleyeceği video hakkında ön bilgi edinmesi hedeflenmiştir.

7. Fonun Anlamlılığı ilkesi: Şekil ya da yazıya anlam katacak bir fon olmalıdır. Araştırmacının çektiği fotoğraflar Photoshop (Demo) programıyla uygun olmayan yerleri kesilmiştir. Kesilen fotoğrafların netlik ayarları, renk ayarı, ışık ayarı verilerek düzeltilmiştir. Doğadan çekilen veya arşivden izlenen filmlerin klasörü içerisinde kavramlarla ilgili film bölümleri tespit edilmiştir. Daha sonra bu kısımlar Ulead Media Studio 7 Video Editör (Demo) programı yardımıyla filmin ana kısmından kesilip ses ve görüntü düzenlemeleri yapılmıştır. Düzeltilen resim ve videolar slaytlarda bir araya getirilmiş, arka plan resim ve 
videoları daha anlaşılır gösterdiği için zemin rengi siyah olarak seçilmiştir. Slaytların arka zemini ise duvar kâğıtlarından oluşturulmuştur. Her slâyda uygun fon müziği kullanılmıştır. Fon müziği ile video sesinin birbirine karışması engellenmiştir.

8. Kapalılık ilkesi: Şekiller belirgin olmalı, açık ve yarım bırakılmamalıdır. Özellikle iki boyutlu figürler için şekil tam yapılmalıdır. Öncellikle amaca hizmet den resim ve videolar kullanılmıştır. Bulanık ya da silik olan resimler kullanılmamıştır.

9. Birleştiricilik ilkesi: Birbiriyle benzerliği ve yakınlığı olan nesne ve olaylar ilişkili olarak algılanır ve daha iyi hatırlanır. Tam bir anlam sağlanabilmesi için birbirini tamamlayan resimlerin slaytları ard arda verilmiştir. Ayrıca ilgili yerlerin resimlerinden sonra hazırlanmış olan videosu gelmektedir.

10. Algıda değişmezlik: Öğrencinin önceden bildiği nesneler çok basit çizgilerle verilebilir. Hazırlanan resim ve videolar üzerine öğrencilerin kolaylıkla anlayabileceği yazılar yazılmıştır. Örneğin; çavuş tepede saklanmış buğdayları gösterirken, saklanmış buğdayların resim üzerine gerekli kavram ismi yazılmıştır.

11. Derinlik ilkesi: Doğadaki varlıklar bize yakın ise gerçek ölçüleri ve renkleriyle görünürler. Aynı varlıklar uzaklaştıkça, küçülüyor ve renkleri de soluyor hissini verir. Bu amaca bağlı kalarak bir yerin resmi farklı uzaklıklarda ve farklı açılarda çekilmiştir. Aynı yöntem video hazırlanırken de kullanılmıştır.

12. Yenilik ilkesi: Çalışmada yakın geçmişteki yaşantılara zıt olan durumlara ve yeniye dikkat çekilmiştir. Yapılan literatür araştırmaların bu tarzda materyalin olmadığı görülmüştür. Resim ve videoların slayt olarak birlikte verilmesi ve resimlerin üzerinde kavramların isimlerinin oluşu hazırladığımız materyalin özgünlükleridir.

13. Basitlik ilkesi: Dikkati çekmesi ve üzerinde tutması için, bir görsel aracın elemanları karmaşık değil basit olmalıdır. Bu ilkeye bağlı kalarak hazırlanan resim ve videolar belirli geçiş sürelerinde ve uygun linklerle birbirine bağlanmıştır. Hazırlanan tüm 
slaytların isimleri Word sayfasına yapıştırılarak slayt isimlerine link atılmıştır. Tüm linkler tek linkte birleştirilmiştir.

14. Hedef-davranış ilkesi: Kullanılacak araç, kazanılması öngörülen hedef davranışı oluşturabilecek nitelikte olmalıdır. Materyalin hazırlanma amaçlarına bağlı olarak öğrencinin yaşadığı çevrede var olan tarihi eserleri ve doğal güzellikleri daha iyi tanıyabilmesi için tarihi eserler ve doğal güzellikler teker teker ziyaret edilmiş ve gerekli envanterler alınmıştır. Bu envanterleri bir araya getirerek eğitim materyali hazırlanmıştır.

15. Öğrenciye uygunluk: Kullanılacak araç, öğrencilerin özelliklerine uygun olmalıdır. Hazırlanan materyal ilköğretim ve ortaöğretim çağındaki öğrencilerin seviyelerine uygundur. Öğrencilerin materyalden verim alabilmesi için yaş ve öğrenim düzeylerine uygun renkler, resimler, videolar ve müzikler kullanılmıştır.

Materyalin Hazırlanışı: Araştırmacılar doğadan çekilen ve arşivden seçilen filmleri teker teker izleyerek, özetleri hazırlamış ve filmin ayrıntılarına yönelik sorular oluşturmuşlardır. Filmlerden hangi kavram, kavram döngüleri (çarkları), serbest kavram kümesi, ilişkisel kavram kümesi, koşullu kavram kümesi, kavram ilişkilendirme tablosunun seçileceği not edilmiş, tanımları yazılarak kavram kümesi oluşturulmuştur. Bu kavramların Concept Draw Office Pro, Concept Draw MINDMAP (Demo) araçları yardımı ile ilişkisel, serbest, koşullu kavram öbeği veya kümesi sayfaları hazırlanmıştır. Bazı kavramlar pdf uzantılı dosya olarak hazırlanıp linkler atılmıştır.

Kavramların özgün tanımı için kesilmiş olan kavram filmleri video filmleri Ulead Media Studio 7 Video Editör (Demo) ile görsel veriler ise Adobe Photoshop (Demo) programları yardımı ile düzenlenmiştir. Buradan filmler Flash Encoder ile .mpeg formatından .flv ve Flash 8 ile .swf uzantılı video dosyalarına çevrilmiştir. Flash programıyla hazırlanan bu kavram kümelerine ait filmlerin her birisi, birer klasör içine kodlanarak Macromedia Dreamveaver 8 web editörü ile kavramın tanımı, özellikleri, özgünlükleri, süresi 
eğitsel fon ve yazı renkleriyle harf sırasına göre düzenlenerek ve ilgili linkler atılarak internet üzerinden yayınlanmak üzere biyoloji eğitimi web sitesine yerleştirilmiştir. Bu web materyalleri (video filmler ve görüntüler, kavram kümlerine ait sayfalar, kavram tanımları) kavram tanımlarıyla eşleştirilerek; Flip Album Suit veya Macromedia Dreamweaver sanal aracı kullanılarak internet entegreli kavram araçları tanım video-görüntüsü hazırlanmıştır. Çekilen videolar, fotoğraflar ve internet ortamında ulaşılan envanterler Adobe Captivate 4 (Demo) programı kullanılarak fotoğraflar ve videolar slaytlar haline getirilerek, arka planları ayarlanmıştır. Slayttın süreleri 12 saniye olarak verilmiş, müzik eklenmiş ve gerekli kavramların isimleri slayttın üzerine yazılmıştır.

Çalışmanın son aşamasında önceki aşamalarda doğadan toplanan, internet, basılı kaynak ve diğer sanal ortamda hazırlanan dokümanlardan edinilen bilgiler kavram merkezli bir arada değerlendirilerek internet üzerinde yayınlanmak üzere biyoloji web sitesi yazılı araştırma basımı ve araştırma DVD'si dokümanı olarak hazırlanmıştır.

Verilerin Toplanması: Araştırmanın nicel boyutu akademik başarı testi ile veri toplanmıştır. Araştırma kapsamında materyal geliştirme ilkeleri ışığında veriler toplanmıştır. Bu kapsamda Van Kale'si surları, kuleleri, kalenin çevresindeki tarihi yapılar, eski Van Evleri, Muradiye Şelale'si, Funda Fast Food salonu ve Yüzüncü Yıl Üniversitesi yerleşkesinde bulunan bazı bitkiler ders materyali olarak kullanılabilecek eğitici ve örnek teşkil edebilecek değişik açılardan fotoğraf ve videoları çekilmiştir. Işık kutusunu kullanarak, resim, hareketsiz cisim ve varlıkların görüntülerini bilgisayara aktarılmış, tarayıcılarla resim ve cisimlere ait üç boyutlu görüntüyü bilgisayara aktarmayı, görüntü ve baskı kalitesinde daha mükemmel sonuca ulaşması sağlanmıştır.

Doğadan çekilen videolar sunu kamerasıyla bilgisayar ortamına aktarılmış, camlı tarayıcı, düz cam yatağı, ışık kutusu, TMA aparatı kullanılarak Photoshop ve Fine Reader OCR aracı ara yüzü ile materyal geliştirmede kullanılmıştır. Ayrıca mikroskop kullanılarak 
veya laboratuvar ortamına getirilen iç organların görüntüleri Ulead Media, Flash ve Dreamweaver sanal araçlarıyla ilgili kavramların internet ve ders sunusu hazırlanmıştır.

Veri Toplama Araçları: Araştırma envanterini Adobe Captivate 4 programı kullanılarak uygun süre ve tanımlar verilerek slayt halinde hazırlanmıştır. Ayrıca Discovery Channel, National Geographical Channel, National Wild. History Channel, Realty TV, BBC Premium... vb. belgesel kanallarından ve çeşitli medya ortamlarından yaklaşık 750 (440 saatlik) bilimsel ve belgesel filmler kayıt edilmiştir. Fotoğraf Makinesi, Video, Kamera, Mikroskop, Sunu Kamerası, Camlı Tarayıcı, Işık Kutusu Aparatı, TMA Aparatı gibi nesnel araçlar ile Ulead Media Video Editörü, Adobe Macromedia Dreamweaver web Editörü, Concept Draw MINDMAP, Flash ve Flash Encoder gibi sanal araçlar da materyalin hazırlanmasında kullanılmıştır. Ayrıca akademik başarı testi uygulanmıştır. Başarı testinin yapı, kapsam ve görünüş geçerlilikleri ile güvenirlik hesaplamaları alan uzmanı bir öğretim üyesi ve bir yüksek lisans öğrencisi tarafından yapılmıştır. Yapılan KR20 güvenirlik hesabın sonucunda güvenirlik değerinin 0,81 olduğu tespit edilmiştir.

Verilerin Analizi: Toplanan veriler alan uzmanı iki öğretmen ve iki öğretim üyesi tarafından analiz edilmiştir. Belgesel filmlerin içeriğinde geçen kavram ve kavram grupların belirlenmesi ve sınıflandırması sürecinde içerik analizi yapılmıştır. Kavramların isimlendirilmesi ve görselleştirilmesi sürecinde uzman görüşü alınmıştır. Hazırlanan kavram filmlere ulaşmada sorun yaşanmaması ve eğitimin aksamaması için filmler .mpeg formatından .flv, ffla ve son olarak .swf formatına dönüştürülmüştür. Akademik başarı testinin analizinde Wann Whitney U-testi kullanılmıştır.

\section{Bulgular ve Yorum}

Kavramlar, filmlerde ve araştırma öğrencisi danışmanı kontrolünde Yüzüncü Y1l Üniversitesi Çevresi, Muradiye Şelalesi, Van Kalesi'ne gidilerek çekilen video ve fotoğraflar, kitaplardan internet web sitelerinden, ders notlarından, Ferit Melen Kütüphanesi veri tabanından elde edilen tezle ilgili önemli bilgiler ve bulgular incelenmiştir. 
1. Klasik ve elektronik sınıfların içerikleri ve karşılaştırmalı görüntüleri: Bir elektronik sınıfta bulunan aletlerin resimleri üzerinde tanımlayıcı isimler kullanılarak tanıtılmıştır.

http://www.biyolojiegitim.yyu.edu.tr/kf/mahmutsinif/mahmutsinif.htm http://www.biyolojiegitim.yyu.edu.tr/ele/index.htm

2. Koşullu doğal kavram kümesi ve özellikleri: Koşullu kavram kümesi ve onun alt kavramları müzik eşliğinde tanımlayıcı isimler kullanılarak tanımlanmıştır.

http://www.biyolojiegitim.yyu.edu.tr/kf/mahmukosullukavramk/mahmukosullukavram k.htm http://www.biyolojiegitim.yyu.edu.tr/f/dol/dol.swf

3. Bir Fast Food'un (ayaküstü hazır yemek) işlevi ve içinde bulunması gerekenler: Bir fast food'da bulunan aletlerin işlevlerini resimler üzerinde tanımlayıcı isimler kullanılarak hazırlanmıştır.

http://www.biyolojiegitim.yyu.edu.tr/kf/mahmutfunda/mahmutfunda.htm

4. Doğal ve yapay 1şık kaynaklarının özgünlükleri ve özellikleri: Doğal ve yapay ışık kaynaklarını müzik eşliğinde, resimler üzerinde tanımlayıcı isimler kullanılarak tanıtılmıştır. http://www.biyolojiegitim.yyu.edu.tr/kf/mahmutisik/mahmutisik.htm

5. Kalelerin özgün ve ortak özellikleri: Van Kalesi, Hoşap Kalesi, Kars Kalesi ve Ardahan Kaleleri müzik eşliğinde resimler, üzerinde tanımlayıcı isimler kullanılarak tanıtılmıştır.

http://www.biyolojiegitim.yyu.edu.tr/kf/mahmutkale/mahmutkale.htm

6. Kavram döngülerinin (çarklarının) özellikleri: Kavram döngülerini müzik eşliğinde, resimler kullanılarak hazırlanmıştır.

http://www.biyolojiegitim.yyu.edu.tr/kf/mahmutkavramcarki/mahmutkavramcarki.htm

7. Kırmızı rengin özellikleri, doğa ve yaşamdaki özgünlükleri: Kırmızı rengi özelliklerini müzik eşliğinde, resimler üzerinde tanımlayıcı isimler kullanılarak tanıtılmıştır. http://www.biyolojiegitim.yyu.edu.tr/kf/mahmutkirmizi/mahmutkirmizi.htm

8. Sarı renginin özellikleri, doğa ve yaşamdaki özgünlükleri: Sarı renginin özelliklerini müzik eşliğinde, resimler üzerinde tanımlayıcı isimler kullanılarak tanıtılmıştır. http://www.biyolojiegitim.yyu.edu.tr/kf/mahmutsari/mahmutsari.htm 
9. Turuncu renginin özellikleri, doğa ve yaşamdaki özgünlükleri: Turuncu renginin özelliklerini müzik eşliğinde, resimler üzerinde tanımlayıcı isimler kullanılarak hazırlanmıştır.

http://www.biyolojiegitim.yyu.edu.tr/kf/mahmutturuncu/mahmutturuncu.htm

10. Yeşil renginin özellikleri, doğa ve yaşamdaki özgünlükleri: Yeşil renginin özelliklerini müzik eşliğinde, resimler üzerinde tanımlayıcı isimler kullanılarak tanıtılmıştır. http://www.biyolojiegitim.yyu.edu.tr/kf/mahmutyesil/mahmutyesil.htm

11. Renklerin bir aradaki özellikleri, doğa ve yaşamdaki özgünlükleri: Renklerin özelliklerini müzik eşliğinde, resimler üzerinde tanımlayıcı isimler kullanılarak tanıtılmıştır. http://www.biyolojiegitim.yyu.edu.tr/kf/mahmutrenkler/mahmutrenkler.htm

12. Kış mevsiminin özellikleri ve özgünlükleri: Kış mevsiminin özelliklerini müzik eşliğinde, resimler üzerinde tanımlayıcı isimler kullanılarak hazırlanmıştır. http://www.biyolojiegitim.yyu.edu.tr/kf/mahmutkis/mahmutkis.htm

13. Yaz mevsiminin özellikleri ve özgünlükleri: Yaz mevsiminin özelliklerini müzik eşliğinde, resimler üzerinde tanımlayıcı isimler kullanılarak tanıtılmıştır.

http://www.biyolojiegitim.yyu.edu.tr/kf/mahmutyaz/mahmutyaz.htm

14. Şelalelerin özgün ve ortak özellikleri (serbest kavram kümesine örnek): Muradiye şelalesinin özellikleri müzik ve video eşliğinde, resimler üzerinde tanımlayıcı isimler kullanılarak verilmiştir.

http://www.biyolojiegitim.yyu.edu.tr/kf/mahmutselale/mahmutselale.htm

15. Yapay ilişkisel kavram kümesinin özellikleri: Kavram haritası kullanılarak alt kavramlara ait bilgileri resim ve açıklayıcı bilgiler kullanılarak tanıtılmıştır.

http://www.biyolojiegitim.yyu.edu.tr/ders/cevbil/cet.html

http://www.biyolojiegitim.yyu.edu.tr/ders/cevbil/kis.html

http://www.biyolojiegitim.yyu.edu.tr/proje/prj.html

16. Doğal ilişkisel kavram kümesinin özellikleri: Kavram haritası kullanılarak alt kavramlara ait bilgileri resim ve açıklayıı bilgiler kullanılarak hazırlanmıştır.

http://www.biyolojiegitim.yyu.edu.tr/ders/oo1.htm\#kavramagi 
http://www.biyolojiegitim.yyu.edu.tr/f/taklit/taklit.swf

17. Kavram ilişkilendirme tablosunun özellikleri: Kavram ilişkilendirme tablosunun bir örneği kullanılmıştır.

http://www.biyolojiegitim.yyu.edu.tr/ders/oo1.htm\#kavramcozumleme

18. YYÜ Zeve Yerleşkesi'nde bitki ve bina kümelerinin özgünlükleri: YYÜ Zeve Yerleşkesi'nde bulunan bitkiler müzik eşliğinde, resimler üzerinde tanımlayıcı isimler kullanılarak tanıtılmış ve bir kümede bulunan özellikler sesli olarak açıklanmıştır http://www.biyolojiegitim.yyu.edu.tr/kf/dilvinkume/dilvinkume.htm 19. Evrendeki en büyük cisimler, nesnel üst kümeler ve üst boşluklardan oluşan evrensel (kozmik) ağ kümesi: Evrenle ilgili kavramların, kavram haritası ve videolarla açıklanmıştır. http://www.biyolojiegitim.yyu.edu.tr/f/evrenselkume.pdf

20. Kurbağanın iç organlarını yaşayarak öğrenme uygulaması: Bir kurbağanın iç organlarını kavram kümesi ve video ile açıklanmıştır.

http://www.biyolojiegitim.yyu.edu.tr/f/kurbaga/kurbaga.swf

21. Makroskobik görüntü, şekiller ve kavramlar: Fen laboratuvarında incelenen çeşitli materyallere ait resim ve isimler verilmiştir.

http://www.biyolojiegitim.yyu.edu.tr/fbl/index.htm http://www.biyolojiegitim.yyu.edu.tr/la/index.htm http://www.biyolojiegitim.yyu.edu.tr/lab/index.htm

22. Sunu kamerasıyla materyal geliştirmek: Sunu kamerasının kullanımı ve uygulamasını video şeklinde anlatılmış ve resimler üzerinde tanımlayıcı isimler kullanılarak tanıtılmıştır.

http://www.biyolojiegitim.yyu.edu.tr/f/sk/sk.htm

23. Camlı tarayıcı (scanner), ışık kutusu ve TMA cihazı aksamlarıyla materyal geliştirmek: Araştırma envanterini internet entegreli olarak hazırlanmış ve Yüzüncü Yı1 Üniversitesi ortaöğretim biyoloji bölümü web sitesine eklenmiştir. Ayrıca hazırlanan materyal DVD haline getirilmiştir.

http://www.biyolojiegitim.yyu.edu.tr/f/taratmaisik/taratmaisik.htm 
Araştırma sonucunda hazırlanan materyalin sınıf ortamında kullanılması sonucunda uygulanan başarı testine ait bulgular Tablo 1'de verilmiştir.

Tablo 1. Akademik başarı testine bağlı olarak hazırlanan Mann whitney U testi istatistiği

\begin{tabular}{llllll}
\hline Gruplar & & Sira ortalaması & Sira toplamı & U & P \\
\hline Deney grubu & 26 & 29,58 & 769 & 206 & 0.39 \\
Kontrol grubu & 24 & 21,08 & 506 & & \\
\hline
\end{tabular}

Tablo 1 incelendiğinde; deney ve kontrol grubuna uygulanan başarı test puanları arasında deney grubu lehine anlamlı bir farklılık olduğunu görülmektedir [U=206, p<.05].

Çalışmada hazırlanan ders materyalinin kavram öğretimini etkili bir şekilde öğrenmeye katkı sağladığı anlaşılmıştır. Kavram eğitiminde, kavram yanılgılarını ve kavram yanlışlıklarını gidermede geleneksel yönteme göre daha etkili olduğu sonucuna varılmıştır. Ayrıca öğrencinin görsel, işitsel, görsel +işitsel duyularını hitap ederek dersi daha zevkli hale getirmiştir. Bu da kavramları somutlaştırarak öğrenmeyi daha kalıcı getirdiği anlaşılmıştır.

\section{Sonuç}

Çalışmanın başlıca amacına bağlı kalarak; sanal ve nesnel öğretim araçlarını kullanarak kavramların doğru öğrenilmesi ve doğru bir şekilde öğretilmesi için öğretim materyali hazırlanmıştır. Bu materyal değişik koşulları, değişik zamanları, değişik mekânları ve değişik hallerdeki bilgileri derli toplu olarak gösterebilen, mevsimsel olarak çekimi tamamlanan doğal ve yapay serbest kavram kümelerine ait doğal ve yapay alandaki videolarla hazırlanmıştır. Materyal kavram öğretimine dayalı olarak ve internet entegreli olarak hazırlanan Fen bilimleri dersleriyle ilişkisel, özgün ve önemli dokümanlar içermektedir. Ayrıca kullanılan kavram ilişkilendirme araçlarının iskeleti Türkçeleştirilmiş, yeniden kategorize edilmiş ve disiplinize edilerek kullanılmıştır. 
Hazırlanan materyalin öğrencilerle beraber kullanımı sonucunda başarılı sonuçlar elde edilmiştir. Konu boyunca kullanılan materyaller sonucunda uygulanan başarı testi neticesinde deney grubu öğrencilerimizin hazırlanan materyaller sayesinde daha başarılı oldukları tespit edilmiştir.

Araştırmanın sonucunda 23 farklı konu üzerinden toplam 25 adet profesyonel ders sunu materyali, internet entegreli olarak hazırlanmıştır.

\section{Öneriler}

Fen bilimleri öğretmen adayının üniversiteye başlamasıyla çevre olanaklarının kullanımı, materyal geliştirme kriterleri, kavram araçları, sanal araçlar ve nesnel araçlar hakkında eğitim görmesi materyal geliştirmede kolaylık sağlayacağı böylelikle öğrencinin veya okulun çevre koşulları incelenerek elde edilen verilerin materyal olarak kullanılabileceği önerilir.

Eğitim fakültesindeki her öğrenci; videodan, sunu kamerasından, 1şık kutusundan, TMA cihazından, mikroskoptan, ses kayıt cihazından, camlı tarayıcıdan, fotoğraf makinesinden ve internetten materyal toplama ve geliştirmeyi alışık tepki haline getirebileceği ve bunu kullanarak ders sunuları hazırlayabileceği önerilir.

Fakültelerde hazırlatılan öğrenci ödevlerinin tümü veya istendik belli bir kısmı anabilim dalı web sayfasında yayınlatılması, öğrencinin yöntem, materyal geliştirme kriterleri, kavram, sanal ve nesnel araçların kullanımına ya da ilişkilerine yönelik güdülerini güçlendireceği düşünülmektedir.

Araştırmada izlenen yöntemin döngüsü örnek alınarak eğitim fakültelerinin ilgili bölümleri benzer çalışmalarla ana bilim dallarının web sayfalarını harekete geçirmeleri önem taşımaktadır. Her anabilim dalı, edindiği bu bilgileri bölgesindeki, yöresindeki branş öğretmenlerine öğretmek üzere olanaklar hazırlamalıdır. Milli Eğitim Bakanlığı birimleri ile işbirliği içerisinde güncellenmek üzere uygun zamanlarda hizmet içi eğitim veya seminer 
çalışması yaparak eğitim alanındaki sanal- nesnel araçları ilgili öğretmenlere kullanmayı ve materyal geliştirmeyi öğretmelidir.

\section{Makalenin Bilimdeki Konumu (Yeri)}

Matematik ve Fen Bilimleri Eğitimi Bölümü/ Fen Bilgisi Eğitimi Anabilim Dalı

\section{Makalenin Bilimdeki Özgünlüğü}

Literatürde mevcut çalışmalar incelendiğinde, sanal ve nesnel öğretim teknoloji araçları kullanarak sanal ders materyali hazırlamaya yönelik çalışmaların eksik olduğu tespit edilmiştir. Nitekim bu çalışma ile özellikle Fen bilimleri dersinin eğitiminde kullanılmak üzere yeni ve özgün sanal ders materyalleri hazırlanmış ve kullanılmak üzere internet ortamına aktarılmıştır.

\section{Kaynaklar}

Akalan, M.E. (2012). Bilgisayar destekli programlı ögretim yaklaşımına göre hazırlanmış ögrretim teknolojileri ve materyal geliştirme dersinin öğrencilerin akademik başarısına etkisi ve ögrrenci görüşleri. Yayınlanmamış Yüksek Lisans Tezi, Gazi Üniversitesi Eğitim Bilimleri Enstitüsü, Ankara

Akamca Özyılmaz, G., (2009). Kavram karikatürleri ve tahmin-gözlem- açıklama teknikleriyle desteklenmiş fen ve teknoloji eğitimi. e- Journal of New World Secince Academy, 4(4), 120-135.

Alev, N., (2004). Eğitim ve bilgi teknolojisinin fen bilimleri öğretiminde etkilerinin algılanması. Türk Fen Ĕ̈itimi Dergisi, 1(1), 3-20.

All, A., Huycke, L., Fisher, M., (2003). Instructional tools for nursing education: Concept maps. Nursing Education Perspectives, 24(6), 311-322.

Arıkan, D., (2006). Web destekli etkin öğrenme uygulamalarının öğretmen adaylarının derse yönelik tutumları üzerindeki etkileri. Ege Eğitim Dergisi, 7(1), 23-41. 
Ata, A., \& Atik, A. (2016). Alternatif bir eğitim-öğretim ortamı olarak video paylaşım siteleri: üniversitelerdeki you tube uygulamaları. Social Sciences, 11(4), 312-325.

Ayaz, M., (2010). Kavramsal araçlara ve kavramsal ilişkilere dayalı fen bilgisinde ders materyali geliştirmek. Yayınlanmamış Yüksek Lisans Tezi, Fen Bilimleri Enstitüsü, Van.

Aydemir Özyurt, E. (2016). Dördüncü sınıf türkçe dersi ögretim programının görsel okuma ve sunu becerilerini geliştirme açısından incelenmesi. Yayınlanmamış Yüksek Lisans Tezi, Bartın Üniversitesi Eğitim Bilimleri Enstitüsü, Bartın.

Bayram, S., (2006). Illköğretimde Materyal Kullanımı. İstanbul: Morpa Kültür Yayınları.

Blanton, P., (2005). Improving student comprehension by thinking about a topic in multiple ways. The Physics Teacher, 43.

Bonastre, O. \& Pina, M., (2006). Cognitive Learning for Distance Education: A Concept Maps Perspective Operations Research Centre. Miguel Hernandez University of Elche, Health Psychology Department Miguel Hernandez University of Elche (Spain).

Chen, L. \& Lai Y., (2008). Application Concept Maps in to Teaching Materials Design: A Case Study of Program Design. Department of Information Management Chaoyang University of Technology, Taiwan.

Çakır, M., (2014). Görsel Kültür ve Küresel Kitle Kültürü. Ankara: Ütopya Yayınevi.

Çokluk, Ö., Yılmaz, K., \& Oğuz, E. (2011). Nitel bir görüşme yöntemi: Odak grup görüşmesi. Kuramsal Eğitimbilim, 4(1), 95-107.

Dalmışlı, F., (2013). Müzik ĕgitiminde materyal geliştirme. Yayınlanmamış Yüksek Lisans Tezi, Pamukkale Üniversitesi Eğitim Bilimleri Enstitüsü, Denizli.

Demirkuş, N. (2017a). Biyolojide Önemli Kavramlar Ders Notları. Yüzüncü Y11 Üniversitesi. http://www.biyolojiegitim.yyu.edu.tr/ders/kav.htmErişim tarihi 08.02.2017 
Demirkuş, N. (2017b). Öğretim Materyali Geliştirme Ders Notlart. Yüzüncü Y1l Üniversitesi.http://www.biyolojiegitim.yyu.edu.tr/ders/otm.htmErişim tarihi 8.02.2017

Gülen, S. (2010). Popüler fizik kavramları içeren görsel ders materyali geliştirme çalışması. Yayınlanmamış Yüksek Lisans Tezi, Yüzüncü Yıl Üniversitesi Fen Bilimleri Enstitüsü, Van.

Gülen, S. (2016a). Fen-teknoloji-mühendislik ve matematik disiplinlerine dayalı argümantasyon destekli fen öğrenme yaklaşımının ögrencilerin ögrrenme ürünlerine etkisi. Yayınlanmamış Doktora Tezi, Ondokuz Mayıs Üniversitesi Eğitim Bilimleri Enstitüsü, Samsun.

Gülen, S. (2016b). Tool of association concept; volume of concept. Participatory Educational Research, Special Issue 2016-II, 45-50.

Gülen, S., \& Demirkuş, N. (2014a). Güneş sistemi ve ötesi: Uzay bilmecesi ünitesinde, Görsel materyalin öğrenci başarısına etkisi. Yüzüncü Yll Üniversitesi Eğitim Fakültesi Dergisi, 11(1), 1-19.

Gülen, S., \& Demirkuş, N. (2014b). Görsel Materyalin Öğrenci Başarısına Etkisi. Saarbrücken: Türkiye Âlim Kitapları.

Gürbüz, R. (2006). Olasılık kavramıyla ilgili geliştirilen öğretim materyallerinin öğrencilerin kavramsal gelişimlerine etkisi. Buca Eğitim Fakültesi Dergisi, 20, 59-68.

Halls, J. (2012). Rapid Video Development for Trainers: How to Create Learning Videos Fast and Affordably. Virginia: American Society for Training \& Development.

Kaya, Z. (2006). Öğretim Teknolojileri ve Materyal Geliştirme. Ankara: Pegem Yayıncılık.

Taş, E. (2011). A new web designed material approach on learning and assessment in science education. Energy Education Science and Technology Part B: Social and Educational Studies, 3(4), 567-578. 
YYÜ Ĕ̈itim Fakültesi Dergisi (YYU Journal Of EducationFaculty),2017; 14(1):1357-1376, http://efdergi.yyu.edu.tr

Taş, E., Gülen, S., Öner, Z., \& Özyürek, C. (2015). The effects of classic and web-designed

Conceptual change texts on the subject of water chemistry. International Electronic Journal of Elementary Education, 7(2), 263-280.

Seferoğlu, S. S. (2006). Öğretim Teknolojileri ve Materyal Tasarımı. Ankara: Pegem Yayınc1lik.

Şahin, S. (2016). Ĕgitimde Bilişim Teknolojileri I-II. Ankara: Pegem Akademi.

Yelken, T. Y. (2009). Öğretmen adaylarının port folyoları üzerinde grup olarak yaratıcılık temelli materyal geliştirmenin etkileri. Eğitim ve Bilim, 34(153), 83-98. 